\title{
Pengaruh Motivasi Belajar Dan Perhatian Orang Tua Terhadap Kesiapan Belajar Peserta Didik
}

\author{
I Komang Sucandra \\ Pendidikan Guru Sekolah Dasar, Universitas Lampung \\ Jl. Prof. Dr. Sumantri Brojonegoro No 1 Bandar Lampung \\ E-mail: komangsucandra@gmail.com
}

\begin{abstract}
Article Info
Abstract

Received Maret 2021

Accepted April 2021

Published April 2021

\section{Keywords:}

Learning readiness, learning motivation, parents' attention

This research was motivated by the phenomenon that the learning readiness of the fifth grade students of public elementary schools in the Raden Intan cluster was low. The research aimed to determine the influence of learning motivation and parents' attention on students' learning readiness. In this research the writer used ex-post facto research. The population of this research consisted 132 students with a sample 56 students who was taken by using probability sampling techniques, namely proportinate stratified random sampling. The data collecting techniques used in this research were observation, interviews, and questionnaires. The data analysis used simple linear regression formula and multiple linear regression. The results showed a positive and significant influence of learning motivation and parents' attention toward students' learning readiness at the fifth grade of elementary school.

Abstrak : Penelitian ini dilatarbelakangi oleh fenomena bahwa kesiapan belajar peserta didik Kelas V SD Negeri di Gugus Raden Intan tergolong rendah. Tujuan penelitian ini adalah untuk mengetahui pengaruh motivasi belajar dan perhatian orang tua terhadap kesiapan belajar peserta didik. Pendekatan kuantitatif dengan metode ex-post facto. Populasi penelitian berjumlah 132 peserta didik dan sampel penelitian berjumlah 56 peserta didik diambil menggunakan teknik probability sampling yaitu proportinate stratified random sampling. Teknik pengumpulan data yang digunakan adalah observasi, wawancara, dan angket. Analisis data menggunakan rumus regresi linear sederhana dan regresi linear berganda. Hasil penelitian menunjukkan pengaruh positif dan signifikan motivasi belajar dan perhatian orang tua terhadap kesiapan belajar peserta didik Kelas V sekolah dasar.
\end{abstract}

Kata Kunci: kesiapan belajar, motivasi belajar, perhatian orang tua

C2021 Jurusan Ilmu Pendidikan, FKIP Universitas Lampung 


\section{PENDAHULUAN}

Pendidikan memegang peranan penting untuk kemajuan suatu bangsa, kualitas sumber daya manusia akan membantu memajukan suatu negara. Sumber daya manusia yang berkualitas tidak diperoleh secara spontan, melainkan melalui proses berkelanjutan mulai manusia dilahirkan sampai meninggal dunia. Proses itulah yang dinamakan pendidikan. Proses pendidikan bukan hanya terjadi di lingkungan sekolah tetapi terjadi juga di dalam lingkungan keluarga. Menurut Helmawati (2014), proses belajar dipengaruhi oleh berbagai faktor, diantaranya adalah lingkungan sosial.

Lingkungan sosial yang lebih banyak mempengaruhi kegiatan belajar peserta didik adalah orang tua. Pendidikan manusia dimulai dari keluarga. Keluarga adalah tempat pertama dan utama bagi pembentukan dan pendidikan anak. Jika ingin membentuk anak yang cerdas serta terampil, maka harus di mulai dari keluarga. Agar terbentuk keluarga yang sehat dan bahagia pun para orang tua perlu pengetahuan yang cukup sehingga mampu membimbing dan mengarahkan setiap anggota keluarga menuju tujuan yang diharapkan.

Sejalan dengan pendapat tersebut, orang tua memiliki peranan yang sangat penting dalam pendidikan anaknya. Hal ini termuat dalam UU No. 20 Tahun 2003 pasal 7 bagian hak dan kewajiban orang tua yang berbunyi:

a. Orang tua berhak berperan serta dalam memilih satuan pendidikan dan memperoleh informasi tentang perkembangan pendidikan anaknya.

b. Orang tua dari anak usia wajib belajar, berkewajiban memberikan pendidikan dasar kepada anaknya.

Dari pendapat tersebut, maka orang tua mempunyai peran yang sangat besar dalam pendidikan anak saat di rumah. Peran orang tua merupakan bentuk perhatian orang tua dalam pendidikan anaknya untuk memberikan yang terbaik demi prestasi yang maksimal. Prestasi atau hasil belajar peserta didik dipengaruhi dari beberapa faktor, baik faktor dari dalam diri maupun luar diri peserta didik tersebut. Menurut Djaali (2009), terdapat fakor yang mempengaruhi hasil belajar.

Faktor yang mempengaruhi pencapaian hasil belajar berasal dari dalam diri orang yang belajar dan ada dari luar dirinya. Faktor yang berasal dari dalam diri peserta didik meliputi kesehatan, intelegensi, minat, motivasi, dan 
cara belajar, sedangkan faktor yang berasal dari luar diri peserta didik meliputi keluarga, sekolah, masyarakat, dan lingkungan sekitar.

Faktor dari dalam diri peserta didik salah satunya adalah motivasi. Menurut Amin (2018), motivasi berasal dari kata bahasa Latin movere yaitu "menggerakan". Motivasi didefinisikan sebagai suatu kondisi yang menyebabkan atau menimbulkan perilaku tertentu, sedangkan menurut Sardiman (2016), motivasi dapat dikatakan sebagai keseluruhan daya penggerak di dalam diri peserta didik yang menimbulkan kegiatan belajar, yang menjamin kelangsungan dari kegiatan belajar dan yang memberikan arah pada kegiatan belajar sehingga tujuan yang dikehendaki oleh subjek belajar tercapai.

Sumber motivasi berasal dari dalam diri dan dari luar diri seseorang. Selain itu, faktor eksternal juga memberikan pengaruh terhadap prestasi belajar, salah satunya adalah perhatian orang tua. Semakin tinggi waktu yang dimiliki orang tua untuk anak-anaknya, maka semakin besar peluang orang tua untuk memberikan perhatian terhadap anak. Perhatian yang cukup dari orang tua akan membuat termotivasi untuk belajar sehingga prestasi belajar peserta didik dapat meningkat.

Motivasi belajar dan perhatian orang tua merupakan faktor dari dalam diri dan luar diri peserta didik untuk meningkatkan prestasi belajarnya. Melalui pengaruh dari kedua faktor tersebut peserta didik diharapkan memiliki kesiapan dalam belajar, kesiapan belajar tersebut akan mempengaruhi bagaimana prestasi belajar atau hasil belajar yang mereka capai. Menurut Slameto (2013), kesiapan adalah keseluruhan kondisi seseorang yang membuatnya siap untuk memberi respon/jawaban di dalam cara tertentu terhadap suatu situasi.

Proses pembelajaran tidak akan maksimal tanpa adanya kesiapan. Menurut Mulyani (2013), peserta didik yang tidak memiliki kesiapan belajar cenderung mendapatkan prestasi belajar yang rendah. Apabila peserta didik siap melakukan proses pembelajaran, maka akan diperoleh hasil belajar yang maksimal. Namun pada kenyataannya, tidak semua faktor tersebut terpenuhi sehingga mengakibatkan timbulnya permasalahan dalam pembelajaran.

Berdasarkan hasil observasi dan wawancara yang dilakukan peneliti pada bulan Desember 2020 terhadap peserta didik Kelas V SD Negeri Gugus Raden Intan Kecamatan Seputih Mataram ditemukan masalah-masalah yang 
berkaitan dengan proses pembelajaran pada saat pandemi Covid, pelaksanaan pembelajaran di sekolah tetap dilakukan namun dengan jadwal belajar yang tidak serentak atau pembelajaran dilakukan secara bergantian dan tetap mematuhi protokol kesehatan. Pada saat peneliti melakukan penelitian pendahuluan ditemukan beberapa peserta didik yang terlihat tidak siap untuk mengikuti pembelajaran terlihat dengan tidak mengerjakan Pekerjaan Rumah (PR), tidak membawa buku pelajaran, tidak berkonsentrasi dalam mengikuti proses pembelajaran dan beberapa peserta didik terlambat datang ke sekolah.

Berdasarkan kondisi tersebut dapat disimpulkan bahwa kesiapan belajar peserta didik dapat dikatakan rendah dengan melihat indikator kesiapan belajar. Data rendahnya kesiapan belajar dapat dilihat pada Tabel 1 data pendukung di bawah ini.

Tabel 1. Rendahnya Kesiapan Belajar Peserta Didik

\begin{tabular}{cccccc}
\hline No. & Nama Sekolah & $\begin{array}{c}\text { Peserta } \\
\text { Didik }\end{array}$ & $\begin{array}{c}\text { Kesiapan Belajar } \\
\text { Rendah (\%) }\end{array}$ & $\begin{array}{c}\text { Kesiapan Belajar } \\
\text { Tinggi (\%) }\end{array}$ & $\begin{array}{c}\text { Total } \\
\text { (\%) }\end{array}$ \\
\hline 1. & SD Negeri 1 Darma Agung & 49 & 67,3 & 32,66 & 100 \\
2. & SD Negeri 2 Darma Agung & 32 & 59,37 & 40,63 & 100 \\
3. & SD Negeri 1 Wirata Agung & 28 & 60,71 & 39,29 & 100 \\
4. & SD Negeri 2 Wirata Agung & 23 & 56,52 & 43,48 & 100 \\
\hline
\end{tabular}

Data diperolah berdasarkan observasi awal menggunakan indikator kesiapan belajar dan pernyataan terlampir. Berdasarkan Tabel 1 tersebut, diketahui bahwa sebagian besar peserta didik kelas V SD Negeri Gugus Raden Intan Kecamatan Seputih Mataram, dilihat dari indikator rendahnya kesiapan belajar peserta didik maka disimpulkan bahwa kesiapan belajar peserta didik tergolong rendah. Untuk SD Negeri 1 Darma Agung sebanyak 17 peserta didik di kelas VA dan sebanyak 16 peserta didik di kelas VB yang memiliki kesiapan belajar rendah berdasarkan indikator atau sebesar 67,34\%. Untuk SD Negeri 2 Darma Agung sebanyak 19 peserta didik di kelas V yang memiliki kesiapan belajar rendah berdasarkan indikator atau sebesar 59,37\%. Untuk SD Negeri 1 Wirata Agung sebanyak 17 peserta didik di kelas V yang memiliki kesiapan belajar rendah berdasarkan indikator atau sebesar $60,71 \%$, kemudian untuk SD Negeri 2 Wirata Agung sebanyak 13 peserta didik di kelas V yang memiliki kesiapan belajar rendah berdasarkan indikator atau sebesar 56,52\%. 
Rendahnya kesiapan belajar peserta didik tersebut diduga dipengaruhi oleh beberapa faktor, peneliti menggali informasi lebih lanjut melalui wawancara dengan peserta didik, dan hasil temuan menyimpulkan bahwa kesiapan belajar peserta didik dipengaruhi oleh faktor internal dari dalam peserta didik yaitu motivasi belajar peserta didik yang rendah serta faktor dari luar diri peserta didik yaitu kurangnya perhatian orang tua dalam kegiatan belajar peserta didik. Hal tersebut berpengaruh terhadap kesiapan belajar peserta didik sehingga menjadi rendah.

Peneliti juga melakukan wawancara terhadap wali kelas dan diperoleh informasi bahwa beberapa peserta didik tidak antusias dalam mengikuti proses pembelajaran, terkadang tidak memperhatikan pendidik ketika menjelaskan materi pelajaran, beberapa peserta didik juga tidak mengerjakan PR yang diberikan oleh pendidik, tidak membawa buku pelajaran, beberapa peserta didik datang terlambat serta terkesan tidak memiliki kesiapan belajar dan motivasi belajar yang rendah.

Berdasarkan hasil observasi yang telah peneliti kemukakan diatas, maka peneliti tertarik melakukan penelitian dengan judul Pengaruh Motivasi Belajar dan Perhatian Orang Tua terhadap Kesiapan Belajar Peserta Didik Kelas V Sekolah Dasar.

\section{METODE}

\section{Jenis Penelitian}

Jenis penelitian yang digunakan dalam penelitian ini adalah jenis penelitian kuantitatif. Metode penelitian yang digunakan peneliti adalah $\mathrm{ex}^{-}$ post facto. Penelitian ini bermaksud menemukan ada tidaknya pengaruh motivasi belajar terhadap kesiapan belajar. Pengaruh perhatian orang tua terhadap kesiapan belajar, dan pengaruh motivasi belajar dan perhatian orang tua terhadap kesiapan belajar peserta didik Kelas V Sekolah Dasar.

\section{Prosedur}

Tahap-tahap penelitian ex-post facto yang telah dilaksanakan adalah sebagai berikut. (1) Memilih subjek penelitian yaitu peseta didik Kelas V Sekolah Dasar di Gugus Raden Intan Seputih Mataram dan subjek uji coba 
instrumen kuesioner (angket) dengan jumlah 20 peserta didik, (2) Menyusun kisi-kisi dan instrumen pengumpul data yang berupa angket, (3) Menguji coba instrumen pengumpul data pada subjek uji coba instrumen yaitu peserta didik Kelas V Sekolah Dasar di Gugus Raden Intan Seputih Mataram, (4) Menganalisis data dari hasil uji coba instrumen untuk mengetahui apakah instrumen yang disusun telah valid dan reliable, (5) Melaksanakan penelitian dengan membagikan instrumen angket kepada sampel penelitian yaitu peserta didik Kelas V Sekolah Dasar di Gugus Raden Intan Seputih Mataram, (6) Menghitung data yang diperoleh untuk mengetahui pengaruh dan tingkat keterkaitan antara motivasi belajar dan perhatian orang tua terhadap kesiapan belajar peserta didik Kelas V Sekolah Dasar di Gugus Raden Intan Seputih Mataram, (7) Interpretasi hasil perhitungan, (8) Melaksanakan penggandaan laporan penelitian.

\section{Populasi dan Sampel}

Populasi penelitian ini adalah peserta didik Kelas V SD Negeri Gugus Raden Intan Seputih Mataram sebanyak 132 peserta didik pada tahun ajaran 2020/2021. Dalam penelitian ini sampel yang diambil menggunakan teknik probability sampling yaitu proportinate stratified random sampling. Menurut Rahayu (2015), proportionate stratified random sampling adalah teknik atau cara pengambilan anggota sampel dari populasi yang tidak homogen dan berstrata secara proporsional. Teknik pengambilan sampel peserta didik Kelas V SD Negeri Gugus Raden Intan Seputih Mataram secara random menggunakan rumus Slovin dalam Amirullah (2015) dengan taraf kesalahan 10\%. Rumus pengambilan sampel sebagai berikut.

$$
n=\frac{N}{1+N(e)^{2}}
$$

Keterangan:

$\mathrm{n} \quad=$ jumlah sampel

$\mathrm{N} \quad=$ ukuran populasi

e = batas kesalahan

Perhitungan sampel dengan rumus di atas sebagai berikut. 


$$
n=\frac{132}{1+132(0,1)^{2}}=\frac{132}{2,34}=56,41=56
$$

Berdasarkan perhitungan sampel di atas, sampel berjumlah 56 peserta didik.

\section{Teknik Pengumpulan Data}

Teknik pengumpulan data merupakan cara-cara yang dilakukan untuk mendapatkan suatu data atau informasi. Data dalam penelitian ini, diperoleh dengan pengumpulan data sebagai berikut. Observasi dalam penelitian ini dilakukan pada saat peneliti melaksanakan penelitian pendahuluan. Selain itu, teknik ini dilakukan untuk memperoleh data tentang kondisi sekolah atau deskripsi tentang lokasi penelitian yang dilaksanakan di SD Negeri Gugus Raden Intan Seputih Mataram. Wawancara dalam penelitian ini dilakukan pada saat peneliti melaksanakan penelitian pendahuluan.

Wawancara dilakukan kepada pendidik dan peserta didik dengan pertanyaan berdasarkan pedoman wawancara yang digunakan untuk mendapatkan informasi atau pendapat pendidik tentang bagaimana motivasi belajar dan kesiapan belajar peserta didik, serta untuk mendapatkan informasi atau pendapat peserta didik tentang bagaimana perhatian orang tua mereka dalam kegiatan belajar. Kuesioner (Angket) ini diberikan kepada peserta didik untuk memperoleh informasi mengenai motivasi belajar, perhatian orang tua dan kesiapan belajar peserta didik. Kuesioner (angket) ini dibuat dengan model Likert yang mempunyai empat kemungkinan jawaban yang berjumlah genap ini dimaksud untuk menghindari kecenderungan responden bersikap ragu-ragu dan tidak mempunyai jawaban yang jelas. Menggunakan skala Likert, maka variabel yang akan diukur dijabarkan menjadi indikator variabel kemudian indikator dijadikan sebagai tolak ukur untuk menyusun item-item instrumen yang dapat berupa pertanyaan atau pernyataan.

\section{Instrumen Penelitian}

Instrumen penelitian ini berupa angket motivasi belajar, perhatian orang tua dan angket kesiapan belajar. Indikator angket motivasi belajar menurut Menurut Sardiman (2016) dan Martin (2010) yaitu (1) Lebih senang bekerja mandiri, (2) Kuatnya kemauan dalam belajar, (3) Ulet menghadapi kesulitan, (4) Senang mencari dan memecahkan masalah soalsoal, (5) Tekun menghadapi tugas. Adapun indikator angket perhatian orang 
tua menurut Kartono (2014) yaitu (1) Memberi Peringatan, (2) Memberi Teguran, (3) Menyediakan Fasilitas Belajar, (4) Mengawasi Waktu Belajar, (5) Mengawasi Kegiatan Belajar, (6) Membantu Kesulitan Belajar. Serta indikator angket kesiapan belajar menurut Djamarah (2010) yaitu (1) Kesiapan Fisik, (2) Kesiapan Psikis, (3) Kesiapan Materiil. Instrumen penelitian diuji coba sebelum digunakan sebagai alat pengumpul data. Tujuan uji coba instrumen ini untuk menentukan validitas dan reliabilitas angket yang dibuat sehingga angket motivasi belajar, perhatian orang tua dan angket kesiapan belajar layak digunakan untuk penelitian dan dapat mengumpulkan data yang sesuai dengan apa yang diteliti.

\section{Teknik Analisis Data}

Teknik analisis data untuk menguji hipotesis menggunakan rumus. Uji Regresi Linear Sederhana yang diungkapkan oleh Siregar (2013) dan Uji Regresi Linear berganda yang diungkapkan Sugiyono (2017) dengan data yang diperoleh dari angket peserta didik kelas V SD Negeri Gugus Raden Intan Kecamatan Seputih Mataram tahun pelajaran 2020/2021. Sebelum dilaksanakan analisis data terlebih dahulu, peneliti harus melakukan pungujian prasyarat analisis dengan menguji normalitas dan linearitas data. Uji hipotesis menggunakan rumus regresi linier sederhana, regresi linear berganda dan uji-F, sedangkan menentukan besar kecilnya kontribusi variabel $\mathrm{X}_{1}$ (Motivasi Belajar) dan $\mathrm{X}_{2}$ (Perhatian Orang Tua) terhadap Y (Kesiapan Belajar) dengan rumus koefisien determinan. Adapun signifikansi pengaruh dilihat dari hasil perhitungan uji $\mathrm{F}$ dengan kaidah: jika $\mathrm{F}_{\text {hitung }}>\mathrm{F}_{\text {tabel, }}$, artinya terdapat pengaruh yang signifikan atau hipotesis penelitian diterima. Sedangkan jika $\mathrm{F}_{\text {hitung }}<\mathrm{F}_{\text {tabel}}$, artinya tidak terdapat pengaruh yang signifikan atau hipotesis penelitian ditolak.

\section{HASIL}

Berdasarkan hasil instrumen angket yang diberikan kepada peserta didik kelas V SD Negeri Gugus Raden Intan Kecamatan Seputih Mataram pada Maret 2021 didapati data sebagai berikut. 
Tabel 2. Data Variabel X dan Y

\begin{tabular}{lccc}
\hline \multicolumn{1}{c}{ Data } & \multicolumn{3}{c}{ Variabel } \\
& $\mathbf{X}_{\mathbf{1}}$ & $\mathbf{X}_{\mathbf{2}}$ & $\mathbf{Y}$ \\
\hline N & 56 & 56 & 56 \\
Skor Terbesar & 48 & 51 & 48 \\
Skor Terkecil & 26 & 25 & 28 \\
$\quad$ Jumlah & 2182 & 2221 & 2257 \\
\hline \multicolumn{4}{c}{} \\
\hline Data & \multicolumn{3}{c}{ Variabel } \\
& $\mathbf{X}_{\mathbf{1}}$ & $\mathbf{X}_{\mathbf{2}}$ & $\mathbf{Y}$ \\
\hline Rerata & 39,07 & 39,78 & 40,42 \\
SD (Standar Deviasi) & 5,58 & 5,34 & 5,63 \\
\hline
\end{tabular}

Pada tabel 1 menunjukkan bahwa simpangan baku (S) variabel kesiapan belajar (Y) sebesar 5,63 rerata sebesar 40,42 dan jumlah skor angket 2257. Hal tersebut berhubungan dengan data variabel motivasi belajar $\left(\mathrm{X}_{1}\right)$ yang memiliki simpangan baku (S) sebesar 5,58 rerata sebesar 39,07 dan jumlah skor angket 2182 dan dengan variabel perhhatia orang tua $\left(\mathrm{X}_{2}\right)$ yang memiliki simpangan baku (S) sebesar 5,34 rerata sebesar 39,78 dan jumlah skor angket 2221.

Berikut deskripsi distribusi frekuensi data variabel $\mathrm{X}_{1}$ (Motivasi Belajar)

Tabel 3. Distribusi Frekuensi Variabel $\mathrm{X}_{1}$

\begin{tabular}{cccc}
\hline No & Interval Nilai & Frekuensi & Persentase (\%) \\
\hline 1 & $26-29$ & 4 & 7,15 \\
2 & $30-33$ & 7 & 12,5 \\
3 & $34-37$ & 6 & 10,71 \\
4 & $38-41$ & 19 & 33,93 \\
5 & $42-45$ & 14 & 25 \\
6 & $46-49$ & 6 & 10,71 \\
& Jumlah & 56 & 100 \\
\hline
\end{tabular}

Berdasarkan Tabel 2, maka penentuan kecenderungan variabel $\mathrm{X}_{1}$ atau motivasi belajar dikategorikan menjadi 3 klasifikasi. Seperti yang disajikan pada Tabel 3.

Tabel 4. Distribusi Kategori Motivasi Belajar

\begin{tabular}{ccccl}
\hline \multirow{2}{*}{ No } & \multirow{2}{*}{ Skor } & \multicolumn{2}{c}{ Frekuensi } & \multirow{2}{*}{ Kategori } \\
\hline 1. & $\geq 44,65$ & 20 & 35,71 & Tinggi \\
2. & $33,49 \leq \mathrm{X}<44,65$ & 25 & 44,65 & Sedang \\
3. & $<33,49$ & 11 & 19,64 & Rendah \\
\hline
\end{tabular}


Berdasarkan Tabel 3 di atas dapat digambarkan dalam pie chart berikut.

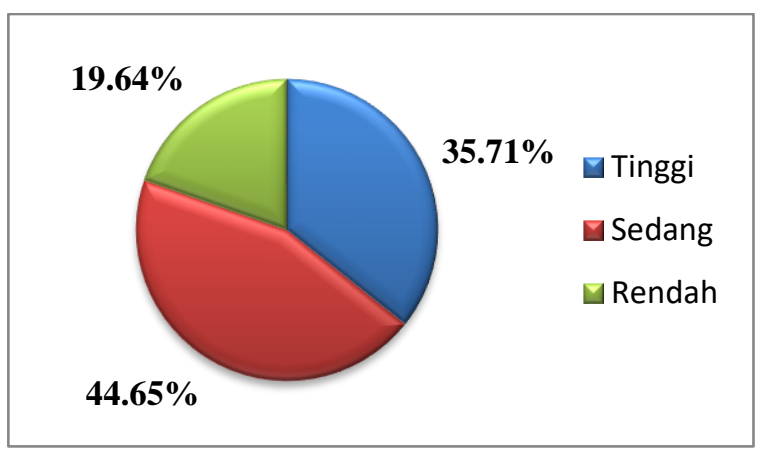

Gambar 1. Pie Chart motivasi belajar

Berdasarkan Gambar 1, maka dapat disimpulkan bahwa dari 56 sampel peserta didik. Peserta didik yang memiliki motivasi belajar tinggi sebanyak 20 peserta didik (35,71\%), yang memiliki motivasi sedang sebanyak 25 peserta didik (44,65\%), dan yang memiliki motivasi belajar rendah sebanyak 11 peserta didik (19,64\%).

\section{Distribusi frekuensi data variabel $\mathrm{X}_{2}$ (Perhatian Orang Tua)}

Tabel 5. Distribusi Frekuensi Variabel $\mathrm{X}_{2}$

\begin{tabular}{cccc}
\hline No & Interval Nilai & Frekuensi & Persentae (\%) \\
\hline 1 & $25-28$ & 3 & 5,36 \\
2 & $29-32$ & 2 & 3,57 \\
3 & $33-36$ & 8 & 14,29 \\
4 & $37-40$ & 14 & 25 \\
5 & $41-44$ & 20 & 35,71 \\
6 & $45-48$ & 8 & 14,28 \\
7 & $49-52$ & 1 & 1,79 \\
& Jumlah & 56 & 100 \\
\hline
\end{tabular}

Berdasarkan Tabel 5, maka penentuan kecenderungan variabel $\mathrm{X}_{2}$ atau perhatian orang tua dikategorikan menjadi 3 klasifikasi. Seperti yang disajikan pada Tabel 6 .

Tabel 6. Distribusi Kategori Perhatian Orang Tua

\begin{tabular}{ccccl}
\hline No & Skor & \multicolumn{2}{c}{ Frekuensi } & Kategori \\
& & Frekuensi & $\%$ & \\
\hline 1. & $\geq 45,12$ & 9 & 16,07 & Tinggi \\
2. & $34,44 \leq X<45,12$ & 42 & 75 & Sedang \\
3. & $<34,44$ & 5 & 8,93 & Rendah \\
\hline
\end{tabular}


Berdasarkan Tabel 6 di atas dapat digambarkan dalam pie chart berikut.

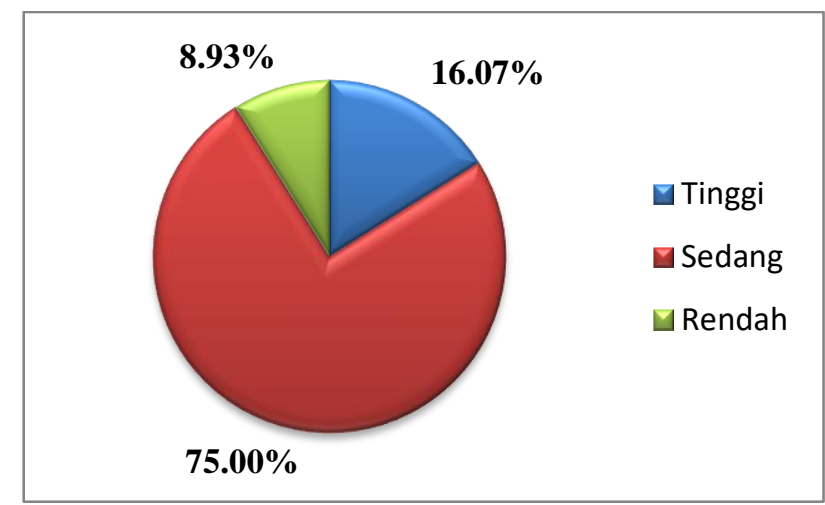

Gambar 2. Pie Chart perhatian orang tua

Berdasarkan Gambar 4, maka dapat disimpulkan bahwa dari 56 sampel peserta didik. Peserta didik yang mendapatkan perhatian dari orang tua dengan kategori tinggi sebanyak 9 peserta didik (16,07\%), yang mendapatkan perhatian orang tua dengan kategori sedang sebanyak 42 peserta didik (75\%), dan yang mendapatkan perhatian orang tua dengan kategori rendah sebanyak 5 peserta didik $(8,93 \%)$.

\section{Distribusi frekuensi data variabel Y (Kesiapan Belajar)}

Tabel 7. Distribusi Frekuensi Variabel Y

\begin{tabular}{cccc}
\hline No & Interval Nilai & Frekuensi & Persentae (\%) \\
\hline 1 & $28-31$ & 5 & 8,93 \\
2 & $32-35$ & 7 & 12,5 \\
3 & $36-39$ & 9 & 16,07 \\
4 & $40-43$ & 16 & 28,57 \\
5 & $44-47$ & 15 & 26,79 \\
6 & $48-51$ & 4 & 7,14 \\
& Jumlah & 56 & 100 \\
\hline
\end{tabular}

Berdasarkan Tabel 7, maka penentuan kecenderungan variabel $\mathrm{Y}$ atau kesiapan belajar dikategorikan menjadi 3 klasifikasi. Seperti yang disajikan pada Tabel 8 .

Tabel 8. Distribusi Kategori Kesiapan Belajar

\begin{tabular}{ccccl}
\hline \multirow{2}{*}{ No } & \multirow{2}{*}{ Skor } & \multicolumn{2}{c}{ Frekuensi } & \multirow{2}{*}{ Kategori } \\
& & Frekuensi & $\%$ & \\
\hline 1. & $\geq 46,05$ & 19 & 33,93 & Tinggi \\
2. & $34,79 \leq X<46,05$ & 32 & 57,14 & Sedang \\
3. & $<34,79$ & 5 & 8,93 & Rendah \\
\hline
\end{tabular}


Berdasarkan Tabel 8 di atas dapat digambarkan dalam pie chart berikut.

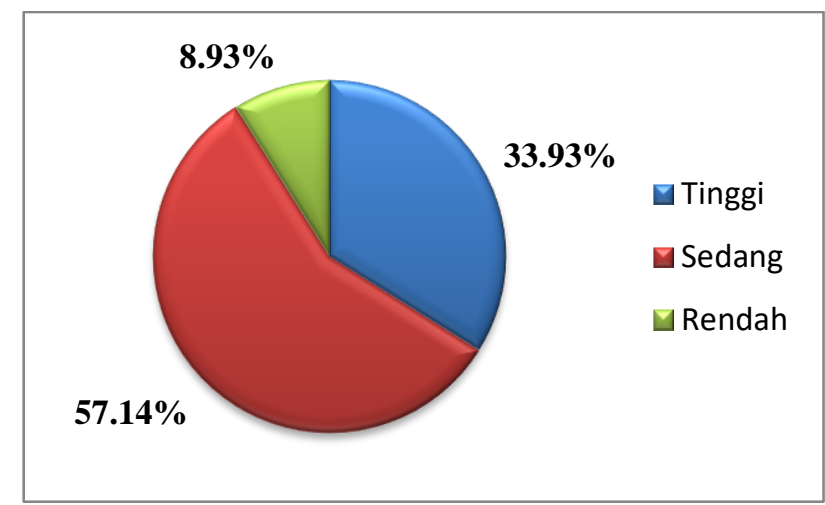

Gambar 3. Pie Chart Kesiapan Belajar

Berdasarkan Gambar 3, maka dapat disimpulkan bahwa dari 56 sampel peserta didik. Peserta didik yang memiliki kesiapan belajar tinggi sebanyak 19 peserta didik (33,93\%), yang memiliki kesiapan belajar sedang sebanyak 32 peserta didik $(57,14 \%)$, dan yang memiliki kesiapan belajar rendah sebanyak 5 peserta didik $(8,93 \%)$.

\section{Perbandingan Motivasi Belajar Antar Sekolah}

Berdasarkan perhitungan data statistik diperoleh data perbandingan rata-rata skor motivasi belajar di setiap sekolah, maka peneliti sajikan dalam histogram berikut.

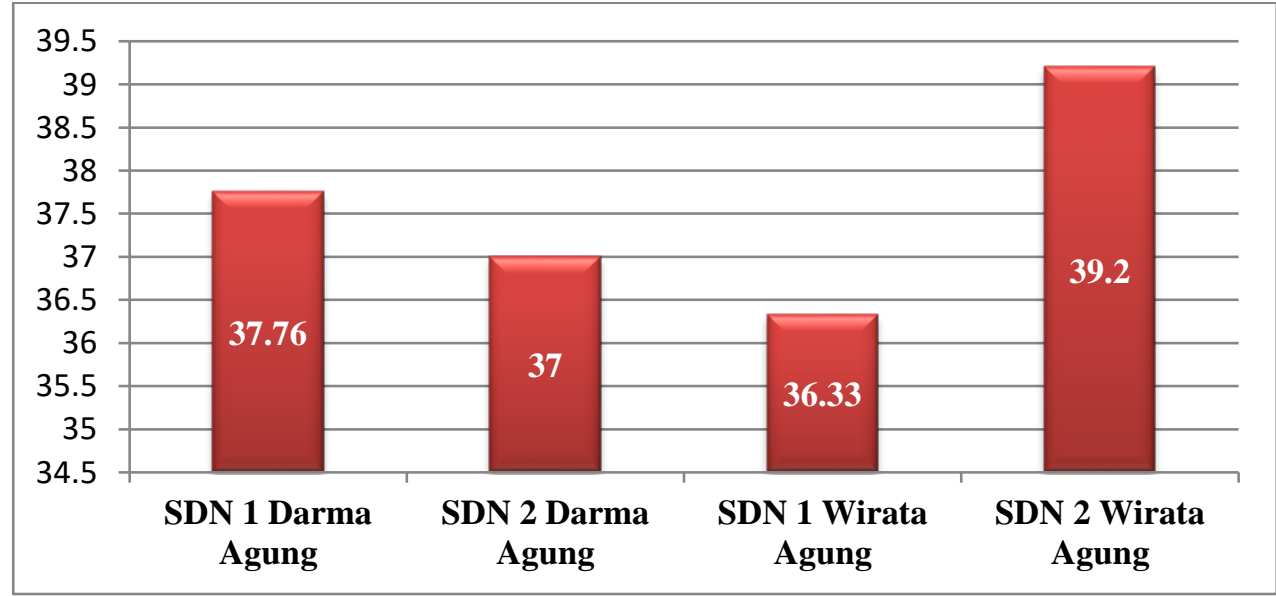

Gambar 4. Histogram Perbandingan Motivasi Belajar

Berdasarkan Gambar 4, rata-rata skor motivasi belajar di setiap sekolah berkategori sedang. Meskipun demikian, rata-rata skor tertinggi yaitu di SD 
Negeri 2 Wirata Agung dan yang terendah yaitu SD Negeri 1 Wirata Agung. Secara rinci untuk mengetahui rata-rata skor dari masing-masing indikator, maka peneliti sajikan pada Tabel 9 .

Tabel 9. Rata-rata Skor Indikator Motivasi Belajar

\begin{tabular}{|c|c|c|c|c|}
\hline Variabel & Dimensi & Indikator & $\begin{array}{l}\text { Rata- }^{-} \\
\text {rata }\end{array}$ & Kategori \\
\hline \multirow{6}{*}{$\begin{array}{l}\text { Motivasi } \\
\text { Belajar }\end{array}$} & \multirow{3}{*}{$\begin{array}{l}\text { Motivasi } \\
\text { Intrinsik }\end{array}$} & 1. Lebih senang bekerja mandiri & 3,3571 & Tinggi \\
\hline & & $\begin{array}{l}\text { 2. Kuatnya kemauan dalam } \\
\text { belajar }\end{array}$ & 3,2142 & Tinggi \\
\hline & & 3. Ulet menghadapi kesulitan & 3,2232 & Tinggi \\
\hline & \multirow{3}{*}{$\begin{array}{l}\text { Motivasi } \\
\text { Ekstrinsik }\end{array}$} & 4. Senang me & & \\
\hline & & $\begin{array}{l}\text { memecahkan masalah soal- } \\
\text { soal }\end{array}$ & 3,1964 & Tinggi \\
\hline & & 5. Tekun menghadapi tugas & 3,2083 & Tinggi \\
\hline
\end{tabular}

Berdasarkan Tabel 9, diperoleh rata-rata skor tiap indikator dengan kategori tinggi. Meskipun demikian, rata-rata skor tertinggi yaitu pada indikator lebih senang bekerja mandiri dan yang terendah yaitu pada indikator senang mencari dan memecahkan masalah soal-soal.

Perbandingan Variabel Perhatian Orang Tua

Berdasarkan perhitungan data statistik diperoleh data perbandingan rata-rata skor perhatian orang tua di setiap sekolah, maka peneliti sajikan dalam histogram berikut.

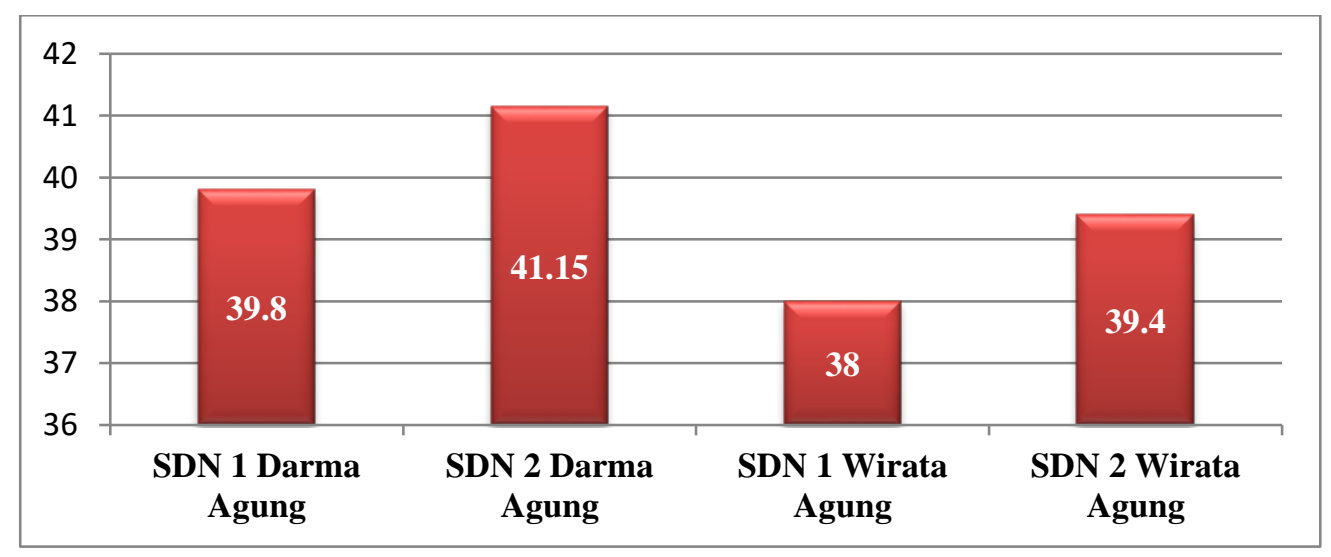

Gambar 5. Histogram Perbandingan Perhatian Orang Tua 
Berdasarkan Gambar 5, rata-rata skor perhatian orang tua di setiap sekolah berkategori sedang. Meskipun demikian, rata-rata skor tertinggi yaitu di SD Negeri 2 Darma Agung dan yang terendah yaitu SD Negeri 1 Wirata Agung. Secara rinci untuk mengetahui rata-rata skor dari masing-masing indikator, maka peneliti sajikan pada Tabel 10.

Tabel 10. Rata-rata Skor Indikator Perhatian Orang Tua

\begin{tabular}{|c|c|c|c|}
\hline Variabel & Indikator & Rata-rata & Kategori \\
\hline \multirow{6}{*}{$\begin{array}{l}\text { Perhatian } \\
\text { orang tua }\end{array}$} & Memberikan peringatan & 3,3392 & Tinggi \\
\hline & Memberikan teguran & 3,0357 & Tinggi \\
\hline & $\begin{array}{l}\text { Menyediakan dan mengatur } \\
\text { waktu belajar }\end{array}$ & 3,0892 & Tinggi \\
\hline & Membantu kesulitan belajar & 2,8482 & Tinggi \\
\hline & Mengawasi kegiatan belajar & 3,1190 & Tinggi \\
\hline & Menyediakan fasilitas belajar & 2,8928 & Tinggi \\
\hline
\end{tabular}

Berdasarkan Tabel 10, diperoleh rata-rata skor tiap indikator dengan kategori tinggi. Meskipun demikian, rata-rata skor tertinggi yaitu pada indikator memberi peringatan dan yang terendah yaitu pada indikator membantu kesulitan belajar.

\section{Perbandingan Variabel Kesiapan Belajar}

Berdasarkan perhitungan data statistik diperoleh data perbandingan rata-rata skor kesiapan belajar di setiap sekolah, maka peneliti sajikan dalam histogram berikut.

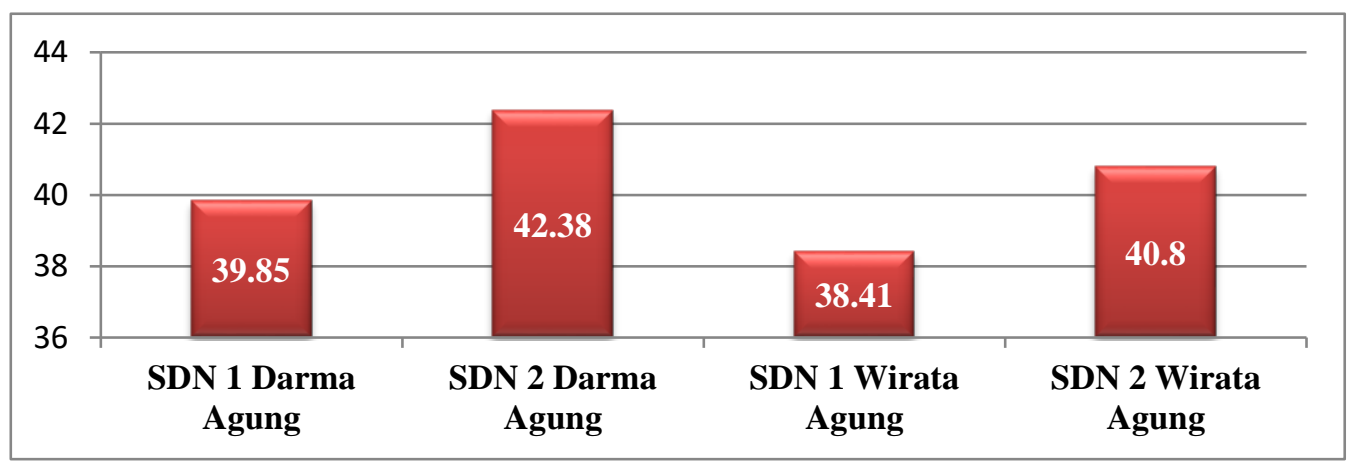

Gambar 6. Histogram Perbandingan Kesiapan Belajar 
Berdasarkan Gambar 6, rata-rata skor kesiapan belajar di setiap sekolah berkategori sedang. Meskipun demikian, rata-rata skor tertinggi yaitu di SD Negeri 2 Darma Agung dan yang terendah yaitu SD Negeri 1 Wirata Agung. Secara rinci untuk mengetahui rata-rata skor dari masing-masing indikator, maka peneliti sajikan pada Tabel 11 .

Tabel 11. Rata-rata Skor Indikator Kesiapan Belajar

\begin{tabular}{|c|cc|c|c|}
\hline Variabel & \multicolumn{2}{|c|}{ Indikator } & Rata-rata & Kategori \\
\hline \multirow{2}{*}{$\begin{array}{c}\text { Kesiapan } \\
\text { Belajar }\end{array}$} & 1. & Kesiapan fisik & 3,4508 & Sangat Tinggi \\
\cline { 2 - 5 } & 2. & Kesiapan psikis & 3,1428 & Tinggi \\
\cline { 2 - 5 } & 3. & Kesiapan materiil & 3,4821 & Sangat Tinggi \\
\hline
\end{tabular}

Berdasarkan Tabel 11, diperoleh rata-rata skor tiap indikator dengan kategori tinggi. Meskipun demikian, rata-rata skor tertinggi yaitu pada indikator kesiapan materiil dan yang terendah yaitu pada indikator kesiapan fsikis.

\section{Uji Prasyaratan Analisis Data}

Terdapat tiga data yang perlu diuji normalitas, yaitu data variabel $\mathrm{X}_{1}$ (Motivasi Belajar), $\mathrm{X}_{2}$ (Perhatian Orang Tua) dan Y (Kesiapan Belajar). Hasil perhitungan uji normalitas variabel $\mathrm{X}_{1}$ dengan menggunakan rumus chi kuadrat. Interpretasi dilakukan dengan membandingkan $\mathrm{X}^{2}$ hitung dengan nilai $\mathrm{X}^{2}$ tabel untuk $\mathrm{a}=0,05$ dan derajat kebebasan $(\mathrm{dk})=\mathrm{k}-1=6-1=5$, pada tabel Chi Kuadrat didapat $\mathrm{X}^{2}$ tabel sebesar 10,070 sehingga sesuai dengan kaidah menyatakan bahwa $\mathrm{X}^{2}$ hitung $=7,060<\mathrm{X}^{2}$ tabel $=10,070$ berarti data variabel $\mathrm{X}_{1}$ berdistribusi normal. Hasil perhitungan uji normalitas variabel $\mathrm{X}_{2}$ dengan menggunakan rumus chi kuadrat. Interpretasi dilakukan dengan membandingkan $\mathrm{X}^{2}$ hitung dengan nilai $\mathrm{X}^{2}$ tabel untuk $\alpha=0,05$ dan derajat kebebasan $(\mathrm{dk})=\mathrm{k}-1=7-1=6$, pada tabel Chi Kuadrat didapat $\mathrm{X}^{2}$ tabel sebesar 12,592 sehingga sesuai dengan kaidah menyatakan bahwa $\mathrm{X}^{2}$ hitung $=9,992<\mathrm{X}^{2}$ tabel $=12,592$ berarti data variabel $\mathrm{X}_{2}$ berdistribusi normal. Sedangkan uji normalitas pada variabel $\mathrm{Y}$ dengan menggunakan rumus chi kuadrat. Interpretasi dilakukan dengan membandingkan $\mathrm{X}^{2}$ hitung dengan nilai $\mathrm{X}^{2}$ tabel 
untuk $\alpha=0,05$ dan derajat kebebasan $(\mathrm{dk})=\mathrm{k}-1=6-1=5$, pada tabel $C h i$ Kuadrat didapat $\mathrm{X}^{2}$ tabel sebesar 10,070 sehingga sesuai dengan kaidah menyatakan bahwa $\mathrm{X}^{2}$ hitung $=5,949<\mathrm{X}^{2}$ tabel $=10,070$ berarti data variabel $\mathrm{X}_{1}$ berdistribusi normal. Berdasarkan uji normalitas yang menyatakan bahwa data variabel $\mathrm{X}_{1}, \mathrm{X}_{2}$ dan $\mathrm{Y}$ berdistribusi normal maka selanjutnya dilakukan uji linearitas.

Hasil Uji Linearitas $\mathrm{X}_{1}$ terhadap Y dapat diinterpretasikan sesuai dengan $\mathrm{F}_{\text {tabel }}$ dengan dk pembilang $=\mathrm{k}-2=21-2=19$ dan dk penyebut $=\mathrm{n}-\mathrm{k}=56-$ $21=35$ dengan $\alpha=0,05$ maka, diperoleh Ftabel $=1,892$, maka $F_{\text {hitung }}=0,327<$ $\mathrm{F}_{\text {tabel }}=1,892$, Hal ini berarti data berpola linear. Sedangkan Uji Linearitas $\mathrm{X}_{2}$ terhadap $\mathrm{Y}$ dapat diinterpretasikan sesuai dengan $\mathrm{F}_{\text {tabel }}$ dengan dk pembilang $=$ $\mathrm{k}-2=20-2=18$ dan $\mathrm{dk}$ penyebut $=\mathrm{n}-\mathrm{k}=56-20=36$ dengan $\mathrm{a}=0,05$ maka, diperoleh $\mathrm{F}_{\text {tabel }}=1,898$, maka $\mathrm{F}_{\text {hitung }}=0,521<\mathrm{F}_{\text {tabel }}=1,898$. Hal ini berarti data berpola linear.

\section{Uji Hipotesis}

Berdasarkan hasil perhitungan uji hipotesis, hasil uji hipotesis pertama diperoleh persamaan garis regresi sebagai berikut, $\mathrm{Y}^{\star}=\alpha+\mathrm{bX}_{1}$ atau $\mathrm{Y}^{\star}=17,95$ + 0,57 X $\mathrm{X}_{1}$ dari Perhitungan menggunakan MS. Excel dapat diketahui nilai r dan $\mathrm{r}^{2}$. Koefisien korelasi $(r)$ menunjukkan nilai positif sebesar 0,5830 yang artinya bahwa motivasi belajar memiliki korelasi dengan kesiapan belajar sebesar 0,5830 atau korelasi berkategori sedang. Koefisien determinasi $\left(r^{2}\right)$ menunjukkan tingkat ketepatan garis regresi dengan nilai sebesar 0,3399. Nilai tersebut berarti 33,99\% perubahan pada variabel kesiapan belajar dapat diterangkan oleh variabel motivasi belajar dan sisanya sebesar 66,01\% diterangkan oleh faktor lain. Pengujian signifikansi atau uji statistik regresi linear sederhana menggunakan uji t. Kriteria pengujian apabila $t$ hitung $>t$ tabel dengan $\alpha=0,05 . \mathrm{DF}=\mathrm{n}-\mathrm{k}-1=56-2=54(\mathrm{t}$ tabel $=2$,00488) nilai $\mathrm{t}$ hitung lebih besar daripada nilai $t$ tabel atau 4,75 $>2,00$. Dengan demikian, Ho ditolak, berarti $\mathrm{Ha}$ diterima. Dengan demikian terdapat pengaruh positif antara variabel $\mathrm{X}_{1}$ dengan $\mathrm{Y}$. Jadi, dapat disimpulkan bahwa terdapat pengaruh motivasi belajar terhadap kesiapan belajar peserta didik Kelas V Sekolah Dasar. 
Hipotesis Kedua diperoleh persamaan garis regresi sebagai berikut, $\mathrm{Y}^{\prime}=$ $26,84+0,33 X_{2}$ dari Koefisien korelasi ( $r$ ) menunjukkan nilai positif sebesar 0,3428 yang artinya bahwa perhatian orang tua memiliki korelasi dengan kesiapan belajar sebesar 0,3428 atau korelasi berkategori rendah. Koefisien determinasi $\left(\mathrm{r}^{2}\right)$ menunjukkan tingkat ketepatan garis regresi dengan nilai sebesar 0,1175 . Nilai tersebut berarti $11,75 \%$ perubahan pada variabel kesiapan belajar dapat diterangkan oleh variabel perhatian orang tua dan sisanya sebesar 88,25\% diterangkan oleh faktor lain. 3. Pengujian signifikansi atau uji statistik regresi linear sederhana menggunakan uji t. Kriteria pengujian apabila $\mathrm{t}$ hitung $>\mathrm{t}$ tabel dengan $\alpha=0,05 . \mathrm{DF}=\mathrm{n}-\mathrm{k}-1=56-2=54(\mathrm{t}$ tabel $=$ 2,00488) nilai thitung lebih besar daripada nilai ttabel atau 2,0625>2,0048. Maka Ho ditolak, berarti Ha diterima. Dengan demikian, terdapat pengaruh positif antara perhatian orang tua terhadap kesiapan belajar peserta didik Kelas V Sekolah Dasar.

Hipotesis ketiga diperoleh persamaan garis regresi sebagai berikut $\mathrm{Y}^{\text {‘ }}=$ $15,75+0,52 \mathrm{X}_{1}+0,09 \mathrm{X}_{2}$. Koefisien korelasi $(\mathrm{r})$ menunjukkan nilai positif sebesar 0,5898 yang artinya bahwa motivasi belajar dan perhatian orang tua secara bersama-sama memiliki korelasi dengan kesiapan belajar sebesar 0,5898 atau korelasi berkategori sedang. Koefisien determinasi $\left(\mathrm{r}^{2}\right)$ menunjukkan tingkat ketepatan garis regresi dengan nilai sebesar 0,3479. Nilai tersebut berarti $34,79 \%$ perubahan pada variabel kesiapan belajar dapat diterangkan oleh variabel motivasi belajar dan perhatian orang tua secara bersama-sama dan sisanya sebesar $65,21 \%$ diterangkan oleh faktor lain. Pengujian signifikansi atau uji statistik regresi linear berganda menggunakan uji F. Berdasarkan di atas, dapat disimpulkan bahwa nilai $\mathrm{F}_{\text {hitung }}=14,141 \mathrm{di}$ atas menunjukkan lebih tinggi dari nilai $\mathrm{F}_{\text {tabel }}=\left(\mathrm{df}_{1}=2 \mathrm{dan}_{\mathrm{df}}=53\right)$ dengan $\mathrm{a}=0,05$ maka diperoleh $\mathrm{F}_{\text {tabel }}=3,17$. Ini berarti persamaan regresi berganda menyatakan kriteria pengujian. Kriteria pengujian: apabila $\mathrm{F}_{\text {hitung }}>\mathrm{F}_{\text {tabel }}$ dengan $\alpha=0,05, \mathrm{Ha}$ diterima dan sebaliknya apabila $\mathrm{F}_{\text {hitung }}<\mathrm{F}_{\text {tabel, }}$ Ha ditolak. Dapat disimpulkan, nilai $\mathrm{F}_{\text {hitung }}>\mathrm{F}_{\text {tabel }}$ atau 14,141 $>$ 3,171. Maka Ha diterima, dengan demikian terdapat pengaruh motivasi belajar dan perhatian orang tua secara bersamasama terhadap kesiapan belajar peserta didik di Kelas V Sekolah Dasar. 


\section{PEMBAHASAN}

Pengaruh Motivasi Belajar terhadap Kesiapan Belajar. Berdasarkan hasil uji statistik terdapat pengaruh motivasi belajar terhadap kesiapan belajar peserta didik. Ini menunjukkan peserta didik siap belajar jika memiliki motivasi belajar yang tinggi. Dengan demikian, perlu untuk mengetahui halhal yang dapat mendukung tumbuhnya motivasi belajar peserta didik. Motivasi belajar tiap peserta didik tentu berbeda-beda, ada lebih senang bekerja mandiri sehingga orang lain tidak perlu terlalu ikut andil yang nantinya akan membuat kesiapan psikis peserta didik terganggu (Sardiman, 2016).

Selain itu motivasi dapat ditingkatkan dengan memperhatikan kebutuhan-kebutuhan fisik dan materiil sehingga peserta didik memiliki kemauan yang kuat untuk belajar, yang nantinya membuat peserta didik mampu memecahkan masalah-masalah dalam belajar (Martin, 2010). Lebih jelas lagi, motivasi belajar berpengaruh terhadap keberlangsungan proses belajar peserta didik. Dengan motivasi belajar yang tinggi, secara psikis peserta didik akan aktif dan produkif dalam proses pembelajaran sehingga akan lebih mudah untuk mendapatkan prestasi belajar yang tinggi. Sebaliknya peserta didik yang motivasi belajarnya rendah maka cenderung mendapatkan prestasi yang rendah (Mulyani, 2013). Hasil penelitian ini juga didukung oleh penelitian terdahulu yang dilakukan oleh Fitriana (2016) yang menyimpulkan terdapat hubungan yang positif dan signifikan antara motivasi belajar dengan hasil belajar. Berdasarkan pembahasan hasil penelitian dan penelitian terdahulu, maka dapat disimpulkan terdapat pengaruh motivasi belajar terhadap kesiapan belajar peserta didik Kelas V SD Negeri di Gugus Raden Intan Kecamatan Seputih Mataram.

Pengaruh Perhatian Orang Tua terhadap Kesiapan Belajar. Berdasarkan hasil uji statistik terdapat pengaruh perhatian orang tua terhadap kesiapan belajar peserta didik. Ini menunjukkan orang tua memiliki peran penting dalam kegiatan belajar peserta didik. Peran orang tua merupakan bentuk perhatian orang tua dalam pendidikan anaknya untuk memberikan yang terbaik demi prestasi (Suryabrata, 2011). Perhatian yang diberikan bukan hanya sekedar memberikan fasilitas belajar, tetapi juga kebutuhan lain peserta didik yang mampu menunjangnya dalam belajar. 
Selain kebutuhan materiil, orang tua juga harus memperhatikan kebutuhan fisik sehingga peserta didik memiliki kesiapan belajar (Djamarah, 2010). Lebih jauh lagi, orang tua harus membantu mengatasi kesulitankesulitan dalam belajar peserta didik, mampu memberikan pengawasan terhadap proses pembelajaran peserta didik, dan mampu memahami kondisi psikis peserta didik. Perhatian yang diberikan tersebut berpengaruh terhadap kesiapan belajarnya sehingga mendapat prestasi belajar yang tinggi. Hasil penelitian ini juga didukung oleh penelitian terdahulu yang dilakukan oleh Awaludin (2019) yang menyimpulkan bahwa terdapat pengaruh yang signifikan dan positif perhatian orang tua dan motivasi belajar terhadap hasil belajar Matematika peserta didik. Berdasarkan pembahasan hasil penelitian dan penelitian terdahulu, maka dapat disimpulkan terdapat pengaruh perhatian orang tua terhadap kesiapan belajar peserta didik Kelas V SD Negeri di Gugus Raden Intan Kecamatan Seputih Mataram.

Pengaruh Motivasi Belajar dan Perhatian Orang Tua terhadap Kesiapan Belajar. Berdasarkan hasil uji statistik, motivasi belajar dan perhatian orang tua berpengaruh terhadap kesiapan belajar peserta didik. Motivasi belajar dari dalam diri peserta didik meliputi kuatnya kamauan dalam belajar, anak senang belajar secara mandiri, mencari dan memecahkan masalah (Sardiman, 2016). Selain motivasi intrinsik tersebut, motivasi belajar peserta didik yang muncul dari dalam diri peserta didik. Motivasi belajar dapat dipengaruhi dari luar diri peserta didik itu sendiri, contohnya dari orang tua. Orang tua dapat menumbuhkan motivasi belajar peserta didik dengan cara memberikan fasilitas-fasilitas belajar yang dibutuhkan peserta didik, orang tua dapat memberikan hadiah ketika peserta didik mendapatkan sebuah prestasi, serta perhatian-perhatian lain yang dapat memotivasi peserta didik (Sardiman, 2016)

Motivasi belajar dari dalam diri akan membuat peserta didik menyiapkan fisiknya untuk siap mengikuti proses pembelajaran. Peserta didik juga akan mampu menyiapkan psikisnya untuk aktif dan produktif mengikuti proses pembelajaran. Pemberian perhatian dari orang tua seperti menyediakan fasilitas belajar tentu saja akan membuat peserta didik siap secara materiil untuk mengikuti proses pembelajaran. Oleh karena itu, motivasi belajar dan perhatian orang tua akan berpengaruh terhadap kesiapan belajar peserta didik 
(Djaali, 2009). Hasil penelitian ini juga didukung oleh penelitian terdahulu yang dilakukan oleh Nurhayati (2015) yang menyimpulkan bahwa terdapat pengaruh yang positif dan signifikan tingkat perhatian orang tua dan motivasi belajar terhadap prestasi belajar Matematika peserta didik.

Berdasarkan pembahasan hasil penelitian dan penelitian terdahulu, maka dapat disimpulkan terdapat pengaruh motivasi belajar dan perhatian orang tua secara bersama-sama terhadap kesiapan belajar peserta didik Kelas V SD Negeri di Gugus Raden Intan Kecamatan Seputih Mataram.

\section{KESIMPULAN}

Berdasarkan hasil penelitian dan pembahasan tentang pengaruh motivasi belajar dan perhatian orang tua terhadap kesiapan belajar peserta didik kelas V Sekolah Dasar di Gugus Raden Intan Kecamatan Seputih Mataram, maka dapat disimpulkan, (1) Terdapat pengaruh yang positif dan signifikan motivasi belajar terhadap kesiapan belajar peserta didik Kelas V Sekolah Dasar. Hal ini dapat diartikan bahwa dengan meningkatnya motivasi belajar, maka secara langsung akan diikuti dengan peningkatan kesiapan belajar peserta didik. (2) Terdapat pengaruh yang positif dan signifikan perhatian orang tua terhadap kesiapan belajar peserta didik Kelas V Sekolah Dasar. Hal ini dapat diartikan bahwa dengan meningkatnya perhatian orang tua, maka kesiapan belajar peserta didik akan meningkat, namun peningkatannya tidak terlalu besar. (3). Terdapat pengaruh yang positif dan signifikan motivasi belajar dan perhatian orang tua secara bersama-sama terhadap kesiapan belajar peserta didik Kelas V Sekolah Dasar. Hal ini dapat diartikan bahwa dengan meningkatnya motivasi belajar dan perhatian orang tua, maka kesiapan belajar peserta didik akan meningkat.

\section{DAFTAR PUSTAKA}

Amin, dkk. (2018). Pola Asuh Orang Tua Dalam Motivasi Belajar Anak. Deepublish, Yogyakarta.

Amirullah. (2015). Sampel dan Populasi (Pemahaman, Jenis, dan Teknik). Bayumedia Publishing, Malang.

Awaludin, M. H. (2019). Pengaruh Perhatian Orang Tua Dan Motivasi Belajar Terhadap Hasil Belajar Matematika Siswa Sd Kelas V Se Dabin Ii 
Kecamatan Tegal Barat Kota Tegal. (Disertasi). Universitas Negeri Semarang, Semarang.

Djaali. (2009). Psikologi Pendidikan. PT Bumi Aksara, Jakarta.

Djamarah. (2010). Guru dan Anak Didik Dalam Interaksi Edukatif. Rineka Cipta, Jakarta.

Fitriana, Eva. (2016). Hubungan Antara Motivasi Belajar Dengan Hasil Belajar Ips Siswa Kelas Iv Sdn Di Gugus Dr. Soetomo Kecamatan Blado Batang. (Skripsi). Universitas Negeri Semarang, Semarang.

Helmawati. (2014). Pendidikan Keluarga. Remaja Rosdakarya, Bandung.

Kartono, Kartini. (2014). Peranan Keluarga Membentuk Anak. Rajawali Press, Jakarta.

Martin, Handoko. (2010). Bimbingan dan Konseling di Sekolah. Kanisius, Yogyakarta.

Mulyani, D. (2013). Hubungan Kesiapan Belajar Siswa dengan Prestasi Belajar. Jurnal Ilmiah Konseling. 2: 27-31.

Nurhayati, Rohmah. (2015). Pengaruh Tingkat Perhatian Orang Tua dan Motivasi Belajar terhadap Prestasi Belajar Matematika Siswa Kelas III SD Muhammadiyah Wirobrajan 3 Yogyakarta. (Skripsi). Universitas PGRI Yogyakarta, Yogyakarta.

Penyusun. (2003). Undang-Undang No. 20 Tahun 2003 Tentang Sistem Pendidikan Nasional. Departemen Agama, Jakarta.

Rahayu, M. M. (2015). Pengaruh Kebiasaan Belajar terhadap Hasil Belajar Matematika. Journal of Elementary Education. 4: 39-45.

Sardiman. (2016). Interaksi \& Motivasi Belajar Mengajar. Rajawali Press, Jakarta.

Siregar, Syofian. (2013). Metode Penelitian Kuantitatif. PT Fajar Interpratama Mandiri, Jakarta.

Slameto. (2013). Belajar dan Faktor-Faktor yang Mempengaruhi. Rineka Cipta, Jakarta.

Suryabrata, Sumadi. (2011). Psikologi Pendidikan. PT Raja Grafindo Persada, Jakarta 